\title{
Effects of calf separation and injection of oxytocin on milk performance and milk composition of the Polish Red cows
}

\author{
Edward Dymnicki', Ewa Sosin-Bzducha² and Marcin Gołębiewski ${ }^{3}$ \\ 'Institute of Genetics and Animal Breeding; Polish Academy of Sciences; Jastrzębiec, Poland, ${ }^{2}$ National Research \\ Institute of Animal Production; Department of Animal Genetic Resources Conservation; Cracow, Poland, ${ }^{3}$ Warsaw \\ University of Life Sciences, Department of Cattle Breeding, Faculty of Animal Science, Warsaw, Poland
}

\begin{abstract}
The aim of this study was to analyse the yield and composition of milk from Polish Red cattle after 12-h isolation of calves. Sixty six Polish Red cows were kept together with calves. Control milkings were carried out once a month after 12-h isolation of calves. Five subsequent milkings after calving were taken under consideration. In the season (May-July 2012) oxytocin $(1 \mathrm{ml}$, $3 \mathrm{~min}$ before control milking) was injected. The milk of cows milked mechanically after $12-\mathrm{h}$ isolation of calves was characterized by a very low fat content (0.47-0.58\%) depending on the month after calving. There were no differences in protein and lactose content compared to the standard composition of cow's milk. The milk yield was $6.16 \mathrm{~kg}$ in the first milking after calving and $3.55-4.01 \mathrm{~kg}$ in the four further milkings. After administration of oxytocin a significant increase of milk was observed in the first $(12.9 \mathrm{~kg})$ and subsequent months of lactation $(8.5-12.4 \mathrm{~kg})$. Milk fat content was significantly higher $(4.14 \%$ in the first and 3.39 $3.86 \%$ in the further milkings).
\end{abstract}

Keywords: Polish Red cattle, suckling, low fat content, milk yield and composition

Abbreviations: CST: calf suckling technique, PR: Polish Red

Archiv Tierzucht 56 (2013) 88, 882-891

doi: $10.7482 / 0003-9438-56-088$

Corresponding author:

Marcin Gołębiewski; email: marcin_golebiewski@sggw.pl

Department of Cattle Breeding, Faculty of Animal Science, Warsaw University of Life Sciences, ul. Ciszewskiego 8, 02-786 Warsaw, Poland

() 2013 by the authors; licensee Leibniz Institute for Farm Animal Biology (FBN), Dummerstorf, Germany. This is an Open Access article distributed under the terms and conditions of the Creative Commons Attribution 3.0 License (http://creativecommons.org/licenses/by/3.0/).
Received: 20 April 2013 Accepted: 25 July 2013 Online: 12 August 2013 


\section{Introduction}

Polish Red (PR) cattle were acknowledged as the only indigenous breed in Poland. Towards the late 1960s, the PR cattle population consists of approximately two million cows. Because of agricultural intensification, this breed has been consistently removed from most of their original area since the 1970s. At the moment there are about 3000 cows under milk recording and in herd-books. About 2300 cows are involved in the genetic resources conservation programme (Sosin-Bzducha et al. 2012). The aim of this programme is to restore and maintain the old type population of PR cattle and to preserve the existing genetic variation.

The farmers who keep PR cows and take part in the conservation programme and the Rural Development Programme are largely dependent on subsidies. Adamczyk et al. (2008) reported that in the case of lifted or even limited subsidies, as many as $80 \%$ of the farmers wanted to abandon cows of this breed in favour of breeds that are more efficient and economically profitable (Boonbrahm et al. 2004b). Many farmers who keep dual-purpose cows, such as the $\mathrm{PR}$, are interested in the suckling system because of relatively low milk yield and production profitability. Gajos \& Dymnicki (2012) stated that this system in case of PR cattle is profitable.

The mixed nursing and suckling system remains popular in many parts of the world (Hernandez et al. 2006, Negrao \& Marnet 2002, Combellas \& Tesorero 2003), especially in ecological or organic farms where calves are kept with their dams for a certain period of time (De Passille et al. 2008). Early separation of the calf from the cow is the basis of the modern industry, but the cow-calf rearing system is useful in organic and ecological farms where healthy rearing and production is required. There are a number of studies reporting on higher weight gains during the suckling period for restricted suckling calves compared to the artificial rearing system (Fallon \& Harte 1980, Boonbrahm et al. 2004a, 2004b, Shamay et al. 2005, Fröberg et al. 2007). Bar-Pelled et al. (1997) reported on a better cow and calf health for the nursing system, higher height at the withers, an earlier age at calving and a tendency towards higher milk production during the first lactation.

The number of ecological farms in conservation programmes is growing every year and the most farms are small family businesses. In the mixed nursing and suckling systems it is difficult to quantify lactation yield. The nursing or suckled cows do not release all their milk during machine milking. Pegram et al. (1991) hold that two methods are most frequently used to measure the milk production of a nursing cow. The first is called Calf Suckling Technique (CST) and involves weighing a calf before and after suckling and the second utilizes oxytocin. The authors consider that both methods give the same results.

The aim of the study was to examine the effects on milk production and fat content of nursing PR cows, milked once a month after 12-h separation of calves, before and after injection of oxytocin.

\section{Material and methods}

Sixty-six cows of the PR breed were kept outdoors at a private farm and housed, fed and treated according to the appropriate guidelines. The cows were fed hay and silage ad libitum in the winter and were pastured in the summer. In the winter season the cows received about $2 \mathrm{~kg}$ concentrate per animal. Water was available ad libitum from float activated water bowls placed outdoors. The cows nursed calves immediately after calving. Control machine milking 
was performed once a month (over the five subsequent months after calving) after 12-h separation of calves. Calves were not present during the control milking. The milk samples were taken immediately after milking by the officer of the Polish Federation of Cattle Breeders and Milk Producers (PFCBMP). The analysis of milk samples was done at the Laboratory of the PFCBMP in Bydgoszcz (Fossomatic 5000 Milkoscan 6000, Combifoss). The milk components analysed were fat content, protein content, lactose content and solids. In the next season, all cows were injected intramuscularly with $1 \mathrm{ml}$ of oxytocin ( $3 \mathrm{~min}$ before milking).

The data were analysed with one-way variance analysis using ANOVA procedure (Statistica 9.1, StatSoft, Inc. Tulsa, OK, USA), with parity or successive milkings as the main factor. Cows for which no information about successive milkings was available were removed from further analysis.

\section{Results}

A significant influence of oxytocin injection on fat content in milk (Table 1) was observed. The average fat concentration in milk of control cows was $0.55 \%$ while in the experimental group it was $3.66 \%$. Also both groups differed in terms of fat content variation. Variation coefficient of the control group was more than twice as high as the variation coefficient of the oxytocin group. Table 2 presents the milk yield (milking after $12 \mathrm{~h}$ of calf separation) and milk composition for successive monthly milkings after calving of control cows. To compute daily yield, this amount should be multiplied by two. Milk yield was the highest during the first month after calving with significant differences in relation to the other months. There were no differences in milk yield between milkings 2-5 $(P \geq 0.05)$. Similar relations were observed in terms of fat concentration changes across the milkings. The highest concentration of milk fat was reported at first month $(0.83 \%)$. There were significant differences between first and other milkings. Additionally, the protein concentration varied across the milkings. The lowest protein level was observed in the 2 nd month. The most significant differences were stated between the 2nd and 4th milking. The pick of the lactose concentration was reported at 2nd milking. Significant differences were observed between the 1st and other milkings.

Table 1

Statistics for fat variable in milk of PR cows in five subsequent milkings after calving (control and oxytocin test)

\begin{tabular}{lccccc}
\hline Variable & \multicolumn{5}{c}{ Milking } \\
Fat & 1 & 2 & 3 & 4 & 5 \\
\hline Control & $\mathrm{N}=29$ & $\mathrm{~N}=29$ & $\mathrm{~N}=28$ & $\mathrm{~N}=16$ & $\mathrm{~N}=10$ \\
Mean $\pm \mathrm{SD}, \%$ & $0.69 \pm 0.42$ & $0.48 \pm 0.37$ & $0.47 \pm 0.2$ & $0.52 \pm 0.36$ & $0.58 \pm 0.3$ \\
Minimum & 0.06 & 0.1 & 0.09 & 0.2 & 0.09 \\
Maximum & 1.68 & 1.85 & 0.83 & 0.93 & 1.09 \\
Variance & 0.17 & 0.14 & 0.04 & 0.04 & 0.11 \\
Var. Coeff. & 60.6 & 77.1 & 43.1 & 40.2 & 56 \\
Oxytocin test & $\mathrm{N}=50$ & $\mathrm{~N}=50$ & $\mathrm{~N}=53$ & $\mathrm{~N}=60$ & $\mathrm{~N}=54$ \\
Mean $\pm \mathrm{SD}, \%$, & $4.14 \pm 1.31$ & $3.39 \pm 0.65$ & $3.5 \pm 0.55$ & $3.41 \pm 0.71$ & $3.86 \pm 0.8$ \\
Minimum & 2.52 & 2.31 & 2.59 & 2.1 & 2.12 \\
Maximum & 7.99 & 5.07 & 5.16 & 6.73 & 5.8 \\
Variance & 1.72 & 0.42 & 0.3 & 0.5 & 0.66 \\
Var. Coeff. & 31.67 & 19.15 & 15.7 & 20.74 & 21.0 \\
\hline
\end{tabular}


Table 2

Milk yield and milk composition of suckled PR cows in five subsequent milkings after calving

\begin{tabular}{lccccccr}
\hline \multicolumn{7}{c}{ Milking (subsequent monthly milkings) } \\
& 1 & 2 & 3 & 4 & 5 & $\mathrm{SE}$ & $P$ \\
& $\mathrm{~N}=37$ & $\mathrm{~N}=37$ & $\mathrm{~N}=36$ & $\mathrm{~N}=24$ & $\mathrm{~N}=13$ & & \\
\hline Milk yield, $\mathrm{kg}$ & $6.16 \pm 3.83^{\mathrm{A}}$ & $4.82 \pm 1.96^{\mathrm{B}}$ & $4.01 \pm 1.45^{\mathrm{B}}$ & $3.64 \pm 1.4^{\mathrm{B}}$ & $3.55 \pm 1.51^{\mathrm{B}}$ & 0.21 & $\leq 0.01$ \\
Fat, \% & $0.83 \pm 0.55^{\mathrm{A}}$ & $0.47 \pm 0.36^{\mathrm{B}}$ & $0.48 \pm 0.29^{\mathrm{B}}$ & $0.58 \pm 0.37^{\mathrm{B}}$ & $0.58 \pm 0.3^{\mathrm{B}}$ & 0.04 & $\leq 0.01$ \\
Protein, \% & $3.4 \pm 0.3^{\mathrm{A}}$ & $3.07 \pm 0.42^{\mathrm{B}}$ & $3.25 \pm 0.35^{\mathrm{AB}}$ & $3.58 \pm 0.44^{\mathrm{AC}}$ & $3.55 \pm 0.39^{\mathrm{AC}}$ & 0.04 & $\leq 0.01$ \\
Lactose, \% & $4.35 \pm 0.68^{\mathrm{A}}$ & $4.87 \pm 0.41^{\mathrm{B}}$ & $4.84 \pm 0.51^{\mathrm{B}}$ & $4.74 \pm 0.45^{\mathrm{B}}$ & $4.57 \pm 0.42^{\mathrm{AB}}$ & 0.05 & $\leq 0.01$ \\
Solids, \% & $9.31 \pm 0.83^{\mathrm{ac}}$ & $8.95 \pm 0.56^{\mathrm{b}}$ & $9.13 \pm 0.46^{\mathrm{ab}}$ & $9.46 \pm 0.57^{\mathrm{C}}$ & $9.31 \pm 0.55^{\mathrm{abC}}$ & 0.05 & 0.02 \\
\hline
\end{tabular}

SE: standard error of the mean, $P>0.05$ : no statistically significant differences, ${ }^{A B C} P \leq 0.01,{ }^{\text {abcd }} P \leq 0.05$

Daily milk yield was twice as high as after oxytocin injection (Table 3). Also milk composition was improved significantly. The biggest changes were observed in fat concentration. Oxytocin injection had an effect on milk yield and fat content. Fat percentage in the first milking with oxytocin was similar to that of »standard« milk (4.14 vs. $4.2 \%$ ) and was much lower at the 2 nd and 3rd milkings. In all cases fat percentage was much lower in milk obtained at milking after 12-h calf separation compared with case of oxytocin injection (0.47-0.8 \% and 3.51-4.14\%). In the oxytocin group the highest differences were also reported between the 1st and the 2nd milking. At 1st milking protein level in the milk of the experimental group was lower than in the control group. Excluding the 2nd milking protein concentration was similar in both groups. The tendencies in lactose changes in both groups were also similar.

Table 3

Milk yield and milk composition of PR suckled cows in five subsequent milkings after calving--oxytocin test

\begin{tabular}{lccccccr}
\hline \multicolumn{7}{c}{ Milking (subsequent } & monthly milkings) \\
& 1 & 2 & 3 & 4 & 5 & SE & $P$ \\
& $\mathrm{~N}=50$ & $\mathrm{~N}=50$ & $\mathrm{~N}=53$ & $\mathrm{~N}=60$ & $\mathrm{~N}=54$ & & \\
\hline Milk yield, kg & $12.92 \pm 4.04^{\mathrm{A}}$ & $12.4 \pm 2.75^{\mathrm{A}}$ & $9.32 \pm 2.7^{\mathrm{B}}$ & $9.98 \pm 3.32^{\mathrm{B}}$ & $8.49 \pm 2.86^{\mathrm{B}}$ & 0.22 & $\leq 0.01$ \\
Fat, \% & $4.14 \pm 1.31^{\mathrm{A}}$ & $3.39 \pm 0.65^{\mathrm{B}}$ & $3.51 \pm 0.55^{\mathrm{B}}$ & $3.41 \pm 0.71^{\mathrm{B}}$ & $3.86 \pm 0.81^{\mathrm{A}}$ & 0.05 & $\leq 0.01$ \\
Protein, \% & $3.34 \pm 0.66^{\mathrm{A}}$ & $3.29 \pm 0.27^{\mathrm{A}}$ & $3.29 \pm 0.23^{\mathrm{A}}$ & $3.53 \pm 0.34^{\mathrm{B}}$ & $3.54 \pm 0.41^{\mathrm{B}}$ & 0.03 & $\leq 0.01$ \\
Lactose, \% & $3.92 \pm 0.63^{\mathrm{A}}$ & $4.9 \pm 0.31^{\mathrm{B}}$ & $4.95 \pm 0.22^{\mathrm{B}}$ & $4.6 \pm 0.42^{\mathrm{C}}$ & $4.78 \pm 0.27^{\mathrm{B}}$ & 0.03 & $\leq 0.01$ \\
Solid, \% & $12.4 \pm 1.46$ & $12.21 \pm 0.67$ & $12.48 \pm 0.64$ & $12.4 \pm 0.84$ & $12.73 \pm 0.93$ & 0.06 & 0.08 \\
\hline
\end{tabular}

SE: standard error of the mean, $P>0.05$ : no statistically significant differences, ${ }^{A B C} P \leq 0.01$

The milk yield of multiparous cows was higher than that of primiparous cows $(P \leq 0.01)$ regardless of oxytocin injection (Table 4 and 5 ). There were no differences in milk composition between cows at the 1st and 2nd lactation in the control group (Table 4). However, the average percentage of milk fat was much lower than breed average (4.2\%), with no difference between primiparous and multiparous cows.

After the oxytocin injection there were no differences in milk components between primiparous and multiparous cows $(P \geq 0.05)$ in the 1st to 3 rd milkings except milk yield, which was higher for multiparous cows in the 1st $(P \leq 0.04)$, 2nd $(P \leq 0.09)$ and $3 \mathrm{rd}(P \leq 0.15)$ milkings (Table 5). Differences in most of milk components between primiparous and multiparous cows were observed in the 4th and 5th milkings. 


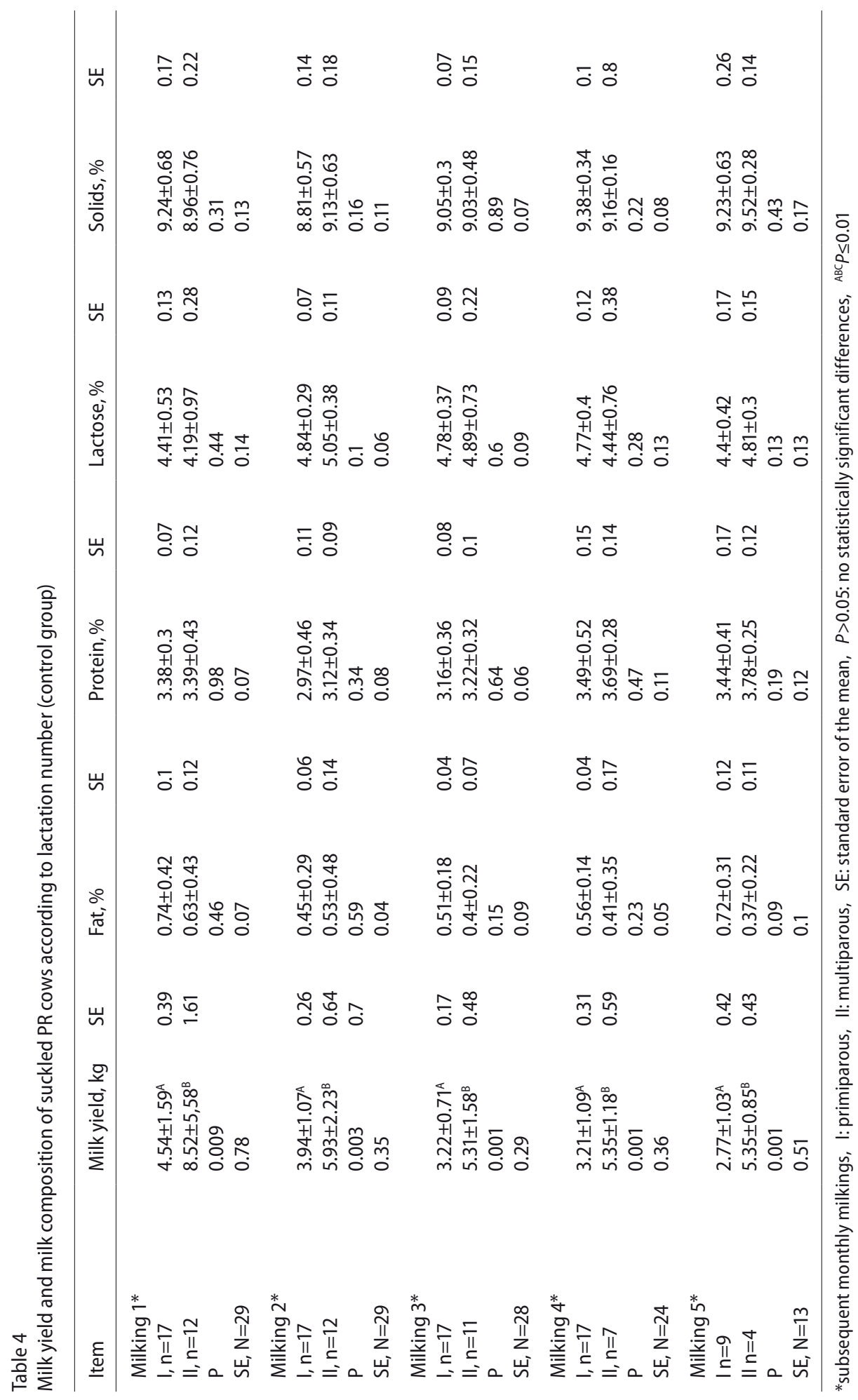




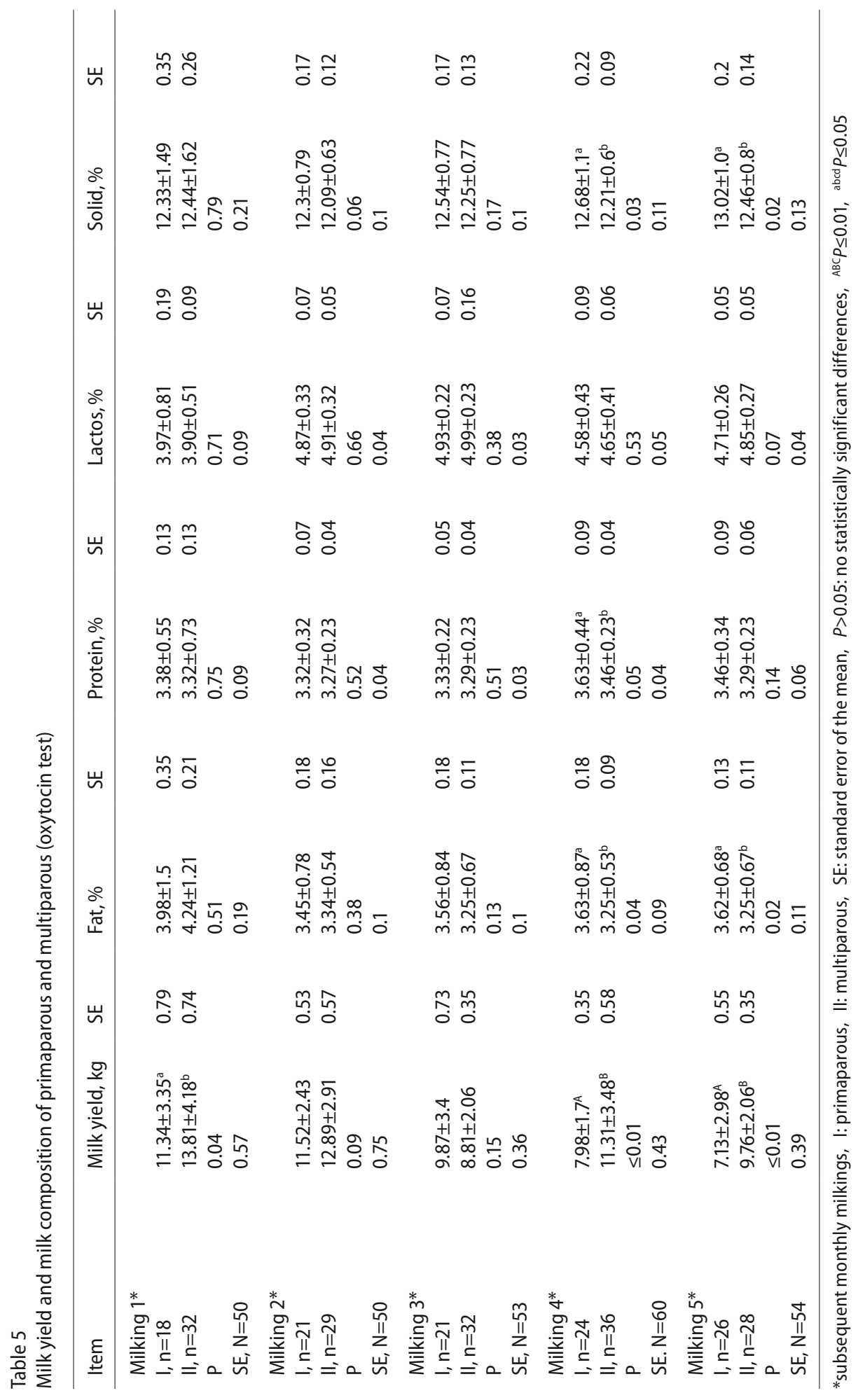




\section{Discussion}

Bar-Pelled et al. (1995) stated that blood oxytocin levels are higher during suckling than during milking. Therefore, such low daily milk yield $(12.32 \mathrm{~kg}$ after calving and $7.1-9.64 \mathrm{~kg}$ in the next monthly milking) can be affected by low concentration of oxytocin. Elevated oxytocin concentrations are necessary during milking for complete milk removal (Bruckmaier et al. 1994, Manteuffel 2002). Wall \& McFadden (2012) stated that oxytocin is involved in elevated milk production elicited by increased milking frequency or suckling. De Passillé (2008) stated that oxytocin levels during the milking of nursing cows (twice daily $2 \mathrm{~h}$ after milking) were much higher $(P \leq 0.03)$ than for machine milked cows $(31.7$ vs. $18.0 \mathrm{pg} / \mathrm{mL})$. The same study confirmed a significant interaction between the type of cow (nursing or machine milked) and phase of lactation. Before nursing the level of oxytocin was the same in both groups (about $14.15 \mathrm{pg} / \mathrm{mL}$ ) and during nursing it increased three-fold in the control group (35.5 vs. $11.0 \mathrm{pg} /$ $\mathrm{mL}$ ). The same significant interactions were noted for prolactin. When suckling is not limited the cows may have reduced oxytocin and prolactin release at milking (Akers \& Lefcourt 1984, Lupoli et al. 2001, Mayntz et al. 2006). Oxytocin is released in response to teat stimulation and prolactin and cortisol are induced both by machine milking or suckling (Bruckmaier \& Blum 1998, Tančin et al. 1995, Williams et al. 1993).

Mao \& Caruolo (1973) reported that mammary blood flow was inversely related to the amount of milk accumulated in the gland and that decreased milk secretion during milk stasis may be mediated by a decreased availability of nutrients for the mammary gland. Farr et al. (2000), noted that extended milk stasis in lactating goats resulted in a 50 to $75 \%$ decrease in mammary blood flow and capillary permeability, as well as a marked regression of vasculature. Twelve-hour separation is probably too short but with factors like stress the mechanism could be the same. Some stress situations, for example, relocation or separation can inhibit oxytocin release and increase prolactin and cortisol concentration (Bruckmaier et al. 1993). Kraetzl et al. (2000) observed no stimulation effect on oxytocin release in cows during suckling by other cow's calf. The positive effect of exogenous oxytocin on milk production was reported in previous studies (Ballou et al. 1993, Lollivier \& Marnet 2005) but Linnerud et al. (1966) claimed that in the absence of milk removal exogenous oxytocin had no effect on milk yield. Bar-Peled (1998) found greater plasma concentrations of growth hormone, prolactin and IGF, and lower insulin concentrations in nursing cows.

The higher milk production of nursing cows may result from hormonal changes.

Low milk fat in milk obtained during a mixed system (suckling and machine milking) was observed in ewes (McKusick et al. 2001, McKusick et al. 2002b, Fuertes et al. 1998) and in cows (Combellas \& Tesorero 2003). No publications on this subject over the last few years have been found. McKusick et al. (2002b) consider that one or all of the following mechanisms are responsible for low fat content in the milk of nursing or suckled ewes at machine milking:

1. milk ejection during machine milking does not occur,

2. milk fat synthesis is inhibited,

3. milk fat transfer from the alveoli to the cistern between milkings does not occur. Combellas \& Tesorero (2003) consider that more than $80 \%$ of milk is stored in udder alveoli and transferred to the cistern by a neurohormonal reflex initiated by the contact of the calf's mouth with the udder. The same authors presented the results of studies carried out to 
evaluate the cow-calf relationship during milking and its effect on milk fractions. Without calf presence, $1-2 \mathrm{~kg}$ less milk was obtained compared to cows stimulated by the calf. Fat content was lower too (1.2\% vs. $2.4-2.7 \%$ respectively). It is well known that the fat content of milk increases during the milking process. Dobicki et al. (1993) reported that fat content was about $3 \%$ in the first litre of milk and about $7 \%$ in the last litre. Similar results were obtained by Dymnicki et al. (2012) (unpublished data). Whittlestone (1953) reported on fat content to be $1.6 \%$ in fore milk and $8.9 \%$ in the fore-strippings. In ewes, McKusick et al. (2002a) stated that the cisternal milk fat but not milk protein percentage was lower than in alveolar milk (4.49\% vs. $7.92 \%)$. The suckled cows do not release all of their milk during machine milking, so that the low fat percentage can be partly attributed to the fact that it is only part of the milk stored in the cistern (Boonbrahm et al. 2004a).

Levy (1964) observed a decrease of about $90 \%$ of fatty acid synthesis in rats by $24 \mathrm{~h}$ of weaning. The synthesis of fatty acids was restored when pups were returned to the mother for suckling. Heesom et al. (1992) suggested that fat synthesis may be regulated by a negative feedback mechanism involving medium-chain fatty acids.

Ewy \& Barowicz (1977) reported that primiparous cows were more responsive to incremental doses of 0.05 to $0.2 \mathrm{IU}$ of oxytocin than multiparous cows. In the present study that was not observed.

The growing interest of farmers in ecological production has increased the interest in native dual-purpose breeds of cattle included in the conservation programme. In Poland the main emphasis was placed for many years on milk production, while beef production was less important. When milk production is uneconomic, especially for small farms, farmers are looking for additional opportunities to improve the profitability. One way is to rear calves with mothers and to produce veal meat on pastures. This method affects the yield and chemical composition of milk, especially milk fat content. Twelve-hour isolation of calves from their mothers is not enough for milk to return to »normal« parameters. The administration of oxytocin restored the standard composition of milk and in part explained the altered composition of the milk of cows nursing their calves.

\section{Acknowledgements}

Partially supported by the National Centre for Research and Development Grant NR12-0166-10.

\section{References}

Adamczyk K, Felenczak A, Jamrozy J, Szarek J, Bulla J (2008) Conservation of Polish Red cattle. Slovak J Anim Sci 41, 72-76

Akers RM, Lefcourt AM (1984) Effect of Presence of Calf on Milking-Induced Release of Prolactin and Oxytocin During Early Lactation of Dairy Cows. J Dairy Sci 67, 115-122

Ballou LU, Bleck JL, Bleck GT, Bremel RD (1993) The Effects of Daily Oxytocin Injections Before and After Milking on Milk Production, Milk Plasmin, and Milk Composition. J Dairy Sci 76, 1544-1549

Bar-Peled U, Aharoni Y, Robinzon B, Bruckental I, Lehrer R, Maltz E, Knight C, Kali J, Folman Y, Voet H, Gacitua H, Tagari H (1998) The Effect of Enhanced Milk Yield of Dairy Cows by Frequent Milking or Suckling on Intake and Digestibility of the Diet. J Dairy Sci 81, 1420-1427 
Bar-Pelled U, Maltz E, Bruckental I, Folman Y, Kali Y, Gacitua H, Lehrer AR, Knight CH, Robinson B, Voet H, Tagari H (1995) Relationship Between Frequent Milking or Suckling in Early Lactation and Milk Production of High Producing Dairy Cows. J Dairy Sci 78, 2726-2736

Bar-Pelled U, Robinzon B, Maltz E, Tagari H, Folman Y, Bruckental I, Voet H, Gacitua H, Lehrer AR (1997) Increased Weight Gain and Effects on Production Parameters of Holstein Heifer Calves That Were Allowed to Suckle from Birth to Six Weeks of Age. J Dairy Sci 80, 2523-2528

Boonbrahm N, Peters K J, Intisang W (2004a) The influence of calf rearing methods and milking methods on performance traits of crossbred dairy cattle in Thailand. 1. Milk yield and udder health. Arch Tierz 47, 211-224

Boonbrahm N, Peters KJ, Kijora C (2004b) The influence of calf rearing methods and milking methods on performance traits of crossbred dairy cattle in Thailand. 3. Calf performance. Arch Tierz 47, 405-414

Bruckmaier RM, Schams D, Blum JW (1993) Milk removal in familiar and unfamiliar surroundings: concentrations of oxytocin, prolactin, cortisol and $\beta$-endorphin. J Dairy Res 60, 449-456

Bruckmaier RM, Blum JW (1998) Oxytocin Release and Milk Removal in Ruminants. J Dairy Sci 81, 939-949

Bruckmaier RM, Schams D, Blum JW (1994) Continuously elevated concentration of oxytocin during milking are necessary for complete milk removal in dairy cows. J Dairy Res 6, 323-334

Combellas J, Tesorero M (2003) Cow-calf relationship during milking and its effect on milk yield and calf live weight gain. Livest Res Rural Dev 15, 1-10

De Passillé AM, Marnet PG, Lapierre H, Rushen J (2008) Effects of Twice-Daily Nursing on Milk Ejection and Milk Yield During Nursing and Milking in Dairy Cows. J Dairy Sci 91, 1416-1422

Dobicki A, Asuquo IB, Adamski M (1993) [Variation of the chemical composition of cow milk sampled at the various stage of milking process]. Przeg Hod 4, 11-14 [in Polish]

Dymnicki E, Gołębiewski M, Szulc T (2012) [Composition of milk throughout the milking process]. In: LXXVII Conference of Polish Society of Animal Production (unpublished data) [in Polish]

Ewy Z, Barowicz T (1977) The influence of the age of cows on the response of myoepithelial cells of the mammary gland following oxytocin injection. Med Wet 33, 385-388 [in Polish]

Fallon RJ, Harte FJ (1980) Methods of feeding milk to young calves. Ir J Agric Res, 19, 67-74

Farr VC, Prosser CG, Davis SR (2000) Effects of mammary engorgement and feed withdrawal on microvascular function in lactating goat mammary glands. Am J Physiol Heart Circ Physiol 279, H1813-H1818

Fröberg S, Aspegren-Güldorff A, Olsson I, Marin B, Berg C, Hernández, Galina CS, Lidfors L, SvennerstenSjaunja K (2007) Effect of restricted suckling on milk yield, milk composition and udder health in cows and behaviour and weight gain in calves, in dual-purpose cattle in the tropics. Trop Anim Health Prod 39, 71-81

Fuertes JA, Gonzalo C, Carriedo JA, San Primitivo F (1998) Parameters of Test Day Milk Yield and Milk Components for Dairy Ewes. J Dairy Sci 81, 1300-1307

Gajos E, Dymnicki E (2012) Beef production based on a suckling system as an alternative to milk production at the example of Polish Red cattle. Anim Sci Pap Rep 30, 353-361

Heesom KJ, Souza PF, llic V, Williamson DH (1992) Chain-length dependency of interactions of medium-chain fatty acids with glucose metabolism in acini isolated from lactating rat mammary glands. A putative feedback to control milk lipid synthesis from glucose. Biochem J 281, 273-278

Hernández C, Orihuela A, Fröberg S, Lidfors LM (2006) Effect of restricted suckling on physiological and behavioural stress parameters in dual-purpose cattle in the tropics. Livest Sci 99, 21-27

Kraetzl WD, Tancin V, Schams D, Bruckmaier RM (2001) Naloxone cannot abolish the lack of oxytocin release during unexperienced suckling of dairy cows. Appl Anim Behav Sci 72, 247-253

Levy HR (1964) The effects of weaning and milk on mammary fatty acid synthesis. Biochim Biophys Acta 84, 229-238

Linnerud AC, Caruolo EV, Miller GE, Marx GD, Donker JD (1966) Lactation Studies. X. Total Daily Production as Affected by Number of Times Milked, Number of Times Stimulated, and Method of Stimulation. J Dairy Sci 49, 1529-1532 
Lollivier V, Marnet PG (2005) Galactopoietic effect of milking in lactating Holstein cows: Role of physiological doses of oxytocin. Livest Prod Sci 95, 131-142

Lupoli B, Johansson B, Uvnäs-Moberg K, Svennersten-Sjaunja K (2001) Effect of suckling on the release of oxytocin, prolactin, cortisol, gastrin, cholecystokinin, somatostatin and insulin in dairy cows and their calves. J Dairy Res 68, 175-187

Manteuffel G (2002) Central nervous regulation of the hypothalamic-pituitary-adrenal axis and its impact on fertility, immunity, metabolism and animal welfare - a review. Arch Tierz 45, 575-595

Mao W, Caruolo EV (1973) Effect of Lactose Content and Milking Interval on Mammary Blood Flow. J Dairy Sci $56,729-732$

Mayntz M, Sender G, Andersson A, Sederström R (2006) The influence of milk withdrawal, stable routines and separation from dam on suckling behaviour of Hereford calves. Arch Tierz 49, 545-560

McKusick BC, Thomas DL, Berger YM (2001) Effect of Weaning System on Commercial Milk Production and Lamb Growth of East Friesian Dairy Sheep. J Dairy Sci 84, 1660-1668

McKusick BC, Thomas DL, Berger YM, Marnet PG (2002a) Effect of Milking Interval on Alveolar Versus Cisternal Milk Accumulation and Milk Production and Composition in Dairy Ewes. J Dairy Sci 85, 2197-2206

McKusick BC, Thomas DL, Romero JE, Marnet PG (2002b) Effect of Weaning System on Milk Composition and Distribution of Milk Fat within the Udder of East Friesian Dairy Ewes. J Dairy Sci 85, 2521-2528

Negrão JA, Marnet PG (2002) Effect of calf suckling on oxytocin, prolactin, growth hormone and milk yield in crossbred Gir x Holstein cows during milking. Reprod Nutr Dev 42, 373-380

Pegram RG, Smith R, Franklin R, Gallagher T, Oosterwijk G, Wilsmore AJ (1991) Comparison of the calf suckling technique and milk oxytocin test for estimation of milk yields. Trop Anim Health Prod 23, 99-102

Shamay A, Werner D, Moallem U, Barash H, Bruckental I (2005) Effect of Nursing Management and Skeletal Size at Weaning on Puberty, Skeletal Growth Rate, and Milk Production During First Lactation of Dairy Heifers. J Dairy Sci 88, 1460-1469

Sosin-Bzducha E, Krupiński J, Bugno-Poniewierska M (2012) Origin and current status of genetic resources conservation programs of cattle. Przeg Hod 10-12, 4-9

Tančin V, Harcek L, Brouček J, Uhrinčat’ M, Mihina Š (1995) Effect of suckling during early lactation and changeover to machine milking on plasma oxytocin and cortisol levels and milk characteristics in Holstein cows. J Dairy Res 62, 249-256

Wall EH, McFadden TB (2012) TRIENNIAL LACTATION SYMPOSIUM: A local affair: How the mammary gland adapts to changes in milking frequency. J Anim Sci 90, 1695-1707

Whittlestone WG (1953) 507. Variations in the fat content of milk throughout the milking process. J Dairy Res 20, 146-153

Williams GL, McVey WR Jr, Hunter JF (1993) Mammary somatosensory pathways are not required for sucklingmediated inhibition of luteinizing hormone secretion and delay of ovulation in cows. Biol Reprod 49, 1328-1337 